\title{
Influence of the Nucleobase on the Physicochemical Characteristics and Biological Activities of $\mathbf{S b}^{\mathrm{V}}$-Ribonucleoside Complexes
}

\author{
Cláudio S. Ferreira, ${ }^{a, b}$ Iara C. M. da Rocha, ${ }^{c}$ Rubens L. M. Neto, ${ }^{b}$ Maria N. Melo, ${ }^{c}$ \\ Frédéric Frézard ${ }^{b}$ and Cynthia Demicheli*a
}

\author{
${ }^{a}$ Departamento de Química, ICEx, ${ }^{b}$ Departamento de Fisiologia e Biofísica, ICB and \\ ${ }^{c}$ Departamento de Parasitologia, ICB,Universidade Federal de Minas Gerais, \\ Av. Antônio Carlos 6627, 31270-901 Belo Horizonte-MG, Brazil
}

\begin{abstract}
A influência da nucleobase (uracila, U; citosina, C; adenina, A; guanina, G) nas propriedades físico-químicas e atividades biológicas in vitro dos complexos $\mathrm{Sb}^{\mathrm{V}}$-ribonucleosídeo foi investigada. Os complexos 1:1 Sb-U e Sb-C foram obtidos no estado sólido e caracterizados por RMN, ESI-MS e análise elementar. As constantes de estabilidade e as constantes aparentes de velocidade de formação e dissociação dos complexos 1:1 Sb-U, Sb-C e Sb-A foram determinadas. Embora o Sb ${ }^{\mathrm{V}}$ se ligue através dos mesmos átomos de oxigênio das posições 2' e 3' nos diferentes nucleosídeos, as mudanças conformacionais na ribose e as propriedades físico-químicas do complexo dependem da nucleobase. A nucleobase influenciou fortemente as atividades citotóxica e leishmanicida dos complexos $\mathrm{Sb}^{\mathrm{V}}$-ribonucleosídeo. Os complexos $\mathrm{Sb}^{\mathrm{V}}$-nucleosídeos purínicos foram mais citotóxicos e eficazes contra a Leishmania chagasi do que os pirimidínicos, o que reforça o modelo de que a interação do $\mathrm{Sb}^{\mathrm{V}}$ com os nucleosídeos purínicos pode mediar a atividade dos medicamentos antimoniais.
\end{abstract}

The influence of the nucleobase (uracyl, U; cytosine, C; adenine, A; guanine, G) on the physicochemical characteristics and in vitro biological activities of $\mathrm{Sb}^{\mathrm{V}}$-ribonucleoside complexes has been investigated. The 1:1 Sb-U and Sb-C complexes were characterized by NMR and ESI-MS spectroscopies and elemental analysis. The stability constant and the apparent association and dissociation rate constants of $1: 1 \mathrm{Sb}^{\mathrm{v}}-\mathrm{U}, \mathrm{Sb}^{\mathrm{V}}-\mathrm{C}$ and $\mathrm{Sb}^{\mathrm{v}}$-A complexes were determined. Although $\mathrm{Sb}^{\mathrm{V}}$ most probably binds via oxygen atoms to the same 2' and $3^{\prime}$ positions in the different nucleosides, the ribose conformational changes and the physicochemical characteristics of the complex depend on the nucleobase. The nucleobase had a strong influence on the cytotoxicity against macrophages and the antileishmanial activity of the $\mathrm{Sb}^{\mathrm{v}}$-ribonucleoside complexes. The $\mathrm{Sb}^{\mathrm{V}}$-purine complexes were more cytotoxic and more effective against Leishmania chagasi than the $\mathrm{Sb}^{\mathrm{v}}$-pyrimidine complexes, supporting the model that the interaction of $\mathrm{Sb}^{\mathrm{V}}$ with purine nucleosides may mediate the antileishmanial activity of pentavalent antimonial drugs.

Keywords: antimony, kinetics, nucleosides, cytotoxicity, leishmaniasis

\section{Introduction}

Two pentavalent organoantimonial complexes, meglumine antimoniate (MA) and sodium stibogluconate, are the first line drugs for the treatment of all forms of leishmaniasis. Despite their clinical use for more than half a century, the mode of action of these drugs remains poorly understood. ${ }^{1}$ It is still not clear whether the final active form of pentavalent antimonials is $\mathrm{Sb}^{\mathrm{V}}$ or $\mathrm{Sb}^{\mathrm{III}}$. According to a first model, $\mathrm{Sb}^{\vee}$ would behave as a prodrug,

*e-mail: demichel@ netuno.lcc.ufmg.br being reduced within the organism into more toxic and active $\mathrm{Sb}^{\mathrm{III}}{ }^{2}$

The formation of $1: 1$ and 1:2 $\mathrm{Sb}^{\mathrm{v}}$-ribonucleoside complexes was evidenced by electrospray ionization mass spectrometry (ESI-MS), nuclear magnetic resonance (NMR) and circular dichroism,,$^{3-6}$ suggesting the involvement of these complexes in the mode of action of pentavalent antimonials. The two different 1:1 and 1:2 $\mathrm{Sb}^{\mathrm{V}}$-adenosine complexes were obtained individually and characterized in the solid state. ${ }^{5}$ Moreover, $\mathrm{Sb}^{\mathrm{V}}$ was found to react with guanosine forming a hydrogel containing a mixture of $1: 1$ and $1: 2 \mathrm{Sb}^{\mathrm{V}}$-guanosine 
complexes. The failure to detect any complex formed between $\mathrm{Sb}^{\mathrm{V}}$ and 2'-deoxyadenosine, adenosine-3,5cyclic monophosphate and 2'-deoxyribose using HPLCES-MS (high performance liquid chromatography - electrospray mass spectrometry) and HPLC-ICP-MS (high performance liquid chromatography - inductively coupled plasma - mass spectrometry) analyses supported the specific binding of $\mathrm{Sb}^{\mathrm{V}}$ to vicinal 2'- and 3'-hydroxyl groups. ${ }^{3,5}$

Kinetic and thermodynamic characterization of the reaction of $\mathrm{Sb}^{\mathrm{V}}$ with 5'-GMP (guanosine monophosphate) showed that complexation was faster at acidic $\mathrm{pH},{ }^{4}$ indicating that it would be kinetically favored in the acidic biological compartments in which Leishmania parasite resides. Moreover, the value of the stability constant determined for the 1:1 $\mathrm{Sb}^{\mathrm{V}}-5^{\prime}$-GMP complex ${ }^{4}$ is consistent with the formation of such complex in the vertebrate host following treatment with pentavalent antimonial drugs, especially if one considers the high accumulation and prolonged retention of antimony in macrophages ${ }^{7}$ which harbor Leishmania parasites. Another remarkable property of $\mathrm{Sb}^{\mathrm{V}}-5^{\prime}$-GMP complexes is their low dissociation rate constant in aqueous solutions at neutral $\mathrm{pH}^{4}$

A model has been suggested for the possible involvement of $\mathrm{Sb}^{\mathrm{V}}$-nucleoside complexes in the leishmanicidal action of pentavalent antimonials. Since Leishmania is a true auxothroph for purine, it has been proposed that $\mathrm{Sb}^{\mathrm{v}}$-purine nucleoside derivatives may inhibit Leishmania purine transporters or act as potent enzyme inhibitors of the purine salvage pathway, as already reported in the case of other purine analogs. ${ }^{8}$

Although much progress has been achieved regarding the physicochemical characterization of $\mathrm{Sb}^{\mathrm{V}}$-ribonucleoside complexes, their pharmacological relevance and the possible influence of the nucleobase on their physicochemical and biological actions still have to be investigated. Accordingly, this paper reports the influence of the nucleobase on the physicochemical characteristics, as well as the cytotoxicity and in vitro antileishmanial activity of $\mathrm{Sb}^{\mathrm{V}}$-ribonucleside complexes.

\section{Experimental}

\section{Materials}

Cytidine (C), uridine (U), adenosine $(\mathrm{A})$ and guanosine (G) were obtained from Sigma Chemical Co. (St. Louis, $\mathrm{MO})$. Potassium antimoniate $\left(\left[\mathrm{KSb}(\mathrm{OH})_{6}\right]\right)$ was obtained from Fluka Chemie $\mathrm{GmbH}$ (> 99\% purity). $\mathrm{SbCl}_{5}(99 \%)$ and $N$-methyl- $D$-glucamine $(99 \%)$ were obtained from Aldrich Chemical Co. (Milwaukee, Wis). All other reagents were of at least reagent grade. Double-distilled-deionized water was used throughout the experiments.

\section{General experimental techniques}

$\mathrm{C}, \mathrm{H}$ and $\mathrm{N}$ analyses were carried out using a Perkin-Elmer 240 Elemental Analyzer. Antimony content was determined by atomic absorption using a HITACHI Z 8200 spectrophotometer. Sb and K were determined by inductively coupled plasma optical emission spectrometry (ICP-OES) using a Perkin Elmer plasma emission spectrometer, model Optima 3000. The content of crystallization water molecules of the synthetic products was determined by thermogravimetric analysis (TGA) using a Shimadzu TGA-50 instrument operating under a nitrogen atmosphere.

${ }^{1} \mathrm{H}$ and ${ }^{13} \mathrm{C}$ NMR spectra were recorded on a Bruker DRX400-AVANCE $\left({ }^{1} \mathrm{H}: 400 \mathrm{MHz} ;{ }^{13} \mathrm{C}: 100 \mathrm{MHz}\right)$ spectrometer using $\mathrm{D}_{2} \mathrm{O}$ as solvent and tms (3-(trimethylsilyl) propionic- $2,2,3,3-d_{4}$ acid, sodium salt) as an internal reference. Heteronuclear multiple quantum correlation (HMQC) and heteronuclear multiple bond coherence (HMBC) spectra for $\mathrm{C}, \mathrm{U}$ and their complexes with $\mathrm{Sb}^{\mathrm{V}}$ were obtained in $\mathrm{D}_{2} \mathrm{O}$. Standard pulse sequences were used for homo- and heteronuclear correlation experiments. The proportions of each species (free ribonucleoside $(\mathrm{Rb})$ and 1:1 Sb-Rb complex) were calculated by integration of the ${ }^{1} \mathrm{H} N M R$ signals corresponding to $\mathrm{H}-6$. The chemical shift for the $\mathrm{H}-6$ of $\mathrm{U}$ was assigned according to a previous reference. ${ }^{9}$

Electrospray mass spectrometry (ESI-MS) analyses were performed on a 2000 QTrap Applied Biosystem equipment. ESI-MS was acquired in the negative mode using $\mathrm{H}_{2} \mathrm{O} / \mathrm{CH}_{3} \mathrm{OH}(1: 1, \mathrm{v} / \mathrm{v})$ solutions of each compound and spraying the solution mixture through the ESI source at $25^{\circ} \mathrm{C}$. Values of $\mathrm{m} / \mathrm{z}$ are reported for the principal ion, that is, for the most abundant isotopomer of the cluster ion.

\section{Preparation of the $S b^{V}-C$ and $S b^{V}-U$ complexes in the solid state}

About $0.9 \mathrm{mmol}$ of ribonucleoside was dissolved in $15 \mathrm{~mL}$ of water and $0.45 \mathrm{mmol}$ of $\left[\mathrm{KSb}(\mathrm{OH})_{6}\right]$ was added to this solution. The $\mathrm{pH}$ of the mixture was adjusted to 7.0 and the solution was kept under stirring at $25{ }^{\circ} \mathrm{C}$. After $24 \mathrm{~h}$, a white precipitate was formed. This precipitate was washed with acetone and dried over $\mathrm{CaCl}_{2}$. A reaction yield of $30-40 \%$ was determined.

$S b^{V}$-cytidine complex: Elemental analysis, found: C, 20.69; H, 3.84; N, 8.02; Sb, 23.50; K, 7.86\%. Calc. for $\mathrm{C}_{9} \mathrm{H}_{15} \mathrm{KN}_{3} \mathrm{O}_{9} \mathrm{Sb}\left(\mathrm{C}_{9} \mathrm{H}_{15} \mathrm{KN}_{3} \mathrm{O}_{9} \mathrm{Sb}+3 \mathrm{H}_{2} \mathrm{O}\right): \mathrm{C}, 20.61 ; \mathrm{H}$, $4.00 ; \mathrm{N}, 8.01 ; \mathrm{Sb}, 23.22 ; \mathrm{K}, 7.50 \%$. $\mathrm{mp} 225^{\circ} \mathrm{C}$ (water). 
$S b^{V}$-uridine complex: Elemental analysis, found: $\mathrm{C}$, $21.60 ; \mathrm{H}, 3.39 ; \mathrm{N}, 5.40 ; \mathrm{Sb}, 24,04 ; \mathrm{K}, 7.67 \%$. Calc. for $\mathrm{C}_{9} \mathrm{H}_{14} \mathrm{KN}_{2} \mathrm{O}_{10} \mathrm{Sb}\left(\mathrm{C}_{9} \mathrm{H}_{14} \mathrm{KN}_{2} \mathrm{O}_{10} \mathrm{Sb}+1.7 \mathrm{H}_{2} \mathrm{O}\right): \mathrm{C}, 21.53$; $\mathrm{H}, 3.48$; N, 5.58; Sb, 24.18; K, 7.76\%. mp $225^{\circ} \mathrm{C}$ (water).

Preparation of meglumine antimoniate, $S b^{V}$-adenosine $\left(S b^{V}-A\right)$ complex and $S b^{V}$-guanosine $\left(S b^{V}-G\right)$ hydrogel

Meglumine antimoniate was synthesized, according to Demicheli et al. ${ }^{10}$, from an equimolar mixture in water of $N$-methyl- $D$-glucamine and freshly precipitated, hydrated antimony pentoxide obtained from $\mathrm{SbCl}_{5}$ previously hydrolyzed in water. After precipitation with acetone, the resulting product was dried. The meglumine antimoniate product contained 29\% of Sb by weight, which corresponds to the expected theoretical value for $1: 1 \mathrm{Sb}-N$-methyl- $D$ glucamine complex $\left[\mathrm{C}_{7} \mathrm{H}_{17} \mathrm{NO}_{5} \cdot \mathrm{HSbO}_{3} \cdot 3 \mathrm{H}_{2} \mathrm{O}\right]$.

The 1:1 $\mathrm{Sb}^{\mathrm{v}}$-A complex was obtained in the solid state, as described previously, ${ }^{5}$ with a reaction yield of $20-25 \%$.

The $\mathrm{Sb}^{\mathrm{v}}$-G hydrogel was prepared as reported previously. ${ }^{5}$ Briefly, $\mathrm{G}$ and $\left[\mathrm{KSb}(\mathrm{OH})_{6}\right]$ were co-dissolved in $\mathrm{H}_{2} \mathrm{O}$ at 1:0.75 molar ratio, the $\mathrm{pH}$ was adjusted to 5 and the resulting mixture was kept under stirring at $60{ }^{\circ} \mathrm{C}$ for $1.5 \mathrm{~h}$. After cooling at $25^{\circ} \mathrm{C}$, a translucent hydrogel was obtained.

\section{Formation rate constants of $1: 1 \mathrm{Sb}^{V}$-ribonucleoside complexes}

The initial rates of complex formation $\left(V_{\mathrm{i}}\right)$ were calculated from the concentration of complex formed after $5 \mathrm{~min}$ of reaction between potassium antimoniate and the ribonucleoside in $\mathrm{D}_{2} \mathrm{O}$. The complex concentration was determined through integration of ${ }^{1} \mathrm{H}$ NMR signals corresponding to $\mathrm{H}-6$. In all aqueous solutions $\left(\mathrm{D}_{2} \mathrm{O}\right)$, which contained $0.1 \mathrm{~mol} \mathrm{~L}^{-1} \mathrm{KCl}$, the $\mathrm{pD}$ was adjusted to 6.5 using $\mathrm{DCl}$ or $\mathrm{NaOD}$ and the reaction was run at $37^{\circ} \mathrm{C}$. The value of $\mathrm{pD}$ was obtained from $\mathrm{pH}$ measurements and calculated as: $\mathrm{pD}=\mathrm{pH}+0.4 .{ }^{11}$

The concentrations of nucleoside and antimony were typically either 10 or $20 \mathrm{mmol} \mathrm{L}^{-1}$. In these initial conditions of reaction, the amount of complex formed did not exceed $15 \%$ of the total complex amount at equilibrium. Data were determined as the mean values from three independent experiments.

In the case of cytidine, the reaction partial orders, $\mathrm{n}$ and $\mathrm{m}$, with respect to nucleoside $(\mathrm{Rb})$ and $\mathrm{Sb}$, respectively, were determined according to the following equations:

$V_{\mathrm{i}}=k_{\mathrm{f}}[\mathrm{Rb}]^{\mathrm{n}}[\mathrm{Sb}]^{\mathrm{m}}$ $\ln V_{\mathrm{i}}=\mathrm{n} \ln [\mathrm{Rb}]+\mathrm{m} \ln [\mathrm{Sb}]+\ln k_{\mathrm{f}}$

where $[\mathrm{Rb}]=$ initial concentration of nucleoside, expressed in $\mathrm{mol} \mathrm{L}^{-1}$, $[\mathrm{Sb}]=$ initial concentration of $\mathrm{Sb}\left(\mathrm{mol} \mathrm{L}^{-1}\right)$ and $k_{\mathrm{f}}=$ apparent rate constant for complex formation.

The reaction of cytidine with potassium antimoniate was run in three different conditions:

experiment $1:[\mathrm{Rb}]=5 \mathrm{mmol} \mathrm{L}^{-1}$ and $[\mathrm{Sb}]=10 \mathrm{mmol} \mathrm{L}^{-1}$ experiment $2:[\mathrm{Rb}]=20 \mathrm{mmol} \mathrm{L}^{-1}$ and $[\mathrm{Sb}]=20 \mathrm{mmol} \mathrm{L}^{-1}$ experiment 3: $[\mathrm{Rb}]=20 \mathrm{mmol} \mathrm{L}^{-1}$ and $[\mathrm{Sb}]=10 \mathrm{mmol} \mathrm{L}^{-1}$.

From the results of experiments 1 and 3 and equation 2, the reaction partial order $n$ was determined as $n=1.0 \pm 0.2$. From the results of experiments 2 and 3 and equation 2, the reaction partial order $\mathrm{m}$ was determined as $\mathrm{m}=0.9 \pm 0.2$.

According to these results, $k_{\mathrm{f}}$ could be determined from equation 3 :

$V_{\mathrm{i}}=k_{\mathrm{f}}[\mathrm{Rb}][\mathrm{Sb}]$

$k_{\mathrm{f}}$ was determined for each nucleoside ( $\mathrm{C}, \mathrm{U}$ and $\mathrm{A}$ ) as the mean value obtained from three independent experiments.

Dissociation rate constants for 1:1 S $b^{V}$-ribonucleoside complexes

First, 1:1 $\mathrm{Sb}^{\mathrm{V}}$-nucleoside complexes ( $\mathrm{Sb}^{\mathrm{V}}-\mathrm{C}, \mathrm{Sb}^{\mathrm{V}}-\mathrm{U}, \mathrm{Sb}^{\mathrm{V}}$-A or $\mathrm{Sb}^{\mathrm{V}}-\mathrm{G}$ ) were formed through incubation of $20 \mathrm{mmol} \mathrm{L}^{-1}$ nucleoside with $20 \mathrm{mmol} \mathrm{L}^{-1}$ potassium antimoniate for $2 \mathrm{~h}$ at $60^{\circ} \mathrm{C}$ at $\mathrm{pD}$ 6.5. Dissociation was induced by diluting the mixture from 20 to $1 \mathrm{mmol}$ nucleoside $\mathrm{L}^{-1}$ in $\mathrm{D}_{2} \mathrm{O}$ containing $0.1 \mathrm{~mol} \mathrm{~L}^{-1} \mathrm{KCl}$. The decrease of the complex concentration was then followed as a function of time $(0,2,4,24 \mathrm{~h})$ at $37^{\circ} \mathrm{C}$ and $\mathrm{pD}$ 6.5. The apparent rate constant of complex dissociation $\left(k_{\mathrm{d}}\right)$ was determined from the following equation:

$\ln [\mathrm{SbL}]=k_{\mathrm{d}} \mathrm{t}+\ln [\mathrm{SbL}]_{0}$

where $[\mathrm{SbL}]$ and $[\mathrm{SbL}]_{0}$ are the molar concentrations of the 1:1 complex at time $t$ and time zero, respectively. [SbL] was calculated through integration of ${ }^{1} \mathrm{H}$ NMR signals corresponding to H-6. $k_{\mathrm{d}}$ was determined, for each nucleoside, as the mean value obtained from three independent experiments.

\section{Stability constants for 1:1 SbV-ribonucleoside complexes}

Potassium antimoniate and nucleoside $(\mathrm{C}, \mathrm{U}$ or $\mathrm{A})$ were incubated in $\mathrm{D}_{2} \mathrm{O}$ containing $0.1 \mathrm{~mol} \mathrm{~L}^{-1} \mathrm{KCl}$ at $37^{\circ} \mathrm{C}$ and $\mathrm{pD}$ 6.5 , and the reaction was run until equilibrium as evidenced 
by ${ }^{1} \mathrm{H}$ NMR. The nucleoside and antimony concentrations were typically in the range of 1 to $2 \mathrm{mmol} \mathrm{L}^{-1}$. The stability constant $(K)$ was determined from the following equation:

$K=[\mathrm{SbL}] /[\mathrm{Sb}][\mathrm{L}]$

where $[\mathrm{Sb}]$ and $[\mathrm{L}]$ are the concentrations, expressed in mol $\mathrm{L}^{-1}$, of free (non-complexed) antimoniate and nucleoside. [SbL] and [L] were calculated through integration of ${ }^{1} \mathrm{H}$ NMR signals corresponding to H-6. $K$ was determined, for each nucleoside, as the mean value obtained from three independent experiments.

\section{Biological assays of 1:1 SbV -ribonucleoside complexes}

\section{Parasites and animals}

The Leishmania (leishmania) chagasi (MCAN/ BR/2002/BH400) strain was maintained in hamsters (Mesocricetus auratus) experimentally infected and cryopreserved in the bank of strains (Leishmania Biology Laboratory / UFMG-Brazil). The Leishmania (leishmania) chagasi (MCAN/BR/2002/BH400) amastigotes used in the present study were obtained from the spleen of hamsters experimentally infected. The spleen was ground in RPMI1640 (Cultilab, Brazil) with the aid of a tissue grinder and filtered through a thin nylon. The material was centrifuged at $3000 \mathrm{rpm}$ for $10 \mathrm{~min}$ (Centrifuge Hermle, $2323 \mathrm{~K}$ ) and then subjected to lysis solution for $10 \mathrm{~min}$ at $37{ }^{\circ} \mathrm{C}$. The resulting suspension was centrifuged and the amastigotes were suspended in RPMI-1640 supplemented with 10\% heat inactivated fetal bovine serum (FBS), $100 \mathrm{IU} \mathrm{mL}^{-1}$ penicillin and $100 \mu \mathrm{gL}^{-1}$ streptomycin.

Balb/c mice (male, 6-8 weeks) were obtained from Cebio (Centro de Bioterismo do Instituto de Ciências Biológicas, Universidade Federal de Minas Gerais). Free access was allowed to standard diet and tap water was supplied ad libidum.

\section{Cytotoxicity assay (MTT assay)}

The MTT assay is a semi-automated assay based on the ability of viable cells to reduce the tetrazolium salt MTT [3-(4, 5-dimethylthiazol-2-yl)-2,5-diphenyl tetrazolium bromide] into a colored product, formazan, by the action of the mitochondrial enzyme succinate dehydrogenase. The original protocol was described by Mosmann, $1983 .{ }^{12}$

Thioglycollate $\left(\right.$ Gibco $\left.^{\circledR}\right)$ elicited peritoneal macrophages of Balb/c mice were harvested in RPMI 1640 medium. Cells were plated in 96-well plates (TPP, Switzerland ${ }^{\circledR}$ ) in RPMI medium supplemented with $10 \%$ FBS, and allowed to adhere for $4 \mathrm{~h}$ at $37^{\circ} \mathrm{C}$ in $5 \% \mathrm{CO}_{2}$. The non-adherent cells were then removed by washing with RPMI medium, and the macrophages which adhered to the plates were then treated with $\mathrm{Sb}^{\mathrm{v}}$-ribonucleosides complexes, meglumine antimoniate or antimoniate at $\mathrm{Sb}$ concentrations varying from 10 to $100 \mu \mathrm{g} \mathrm{mL}-1$ for $72 \mathrm{~h}$ at $37^{\circ} \mathrm{C}$ under $5 \% \mathrm{CO}_{2}$. At the end of the period of incubation, $10 \mu \mathrm{L}$ of MTT (Sigma ${ }^{\circledR}$ ) was added to each well and plates were incubated for $4 \mathrm{~h}$ at $37^{\circ} \mathrm{C}$ in $5 \% \mathrm{CO}_{2}$. Enzyme reaction was then stopped by the addition of $100 \mu \mathrm{L}$ of dimethylsulfoxide (dmso) solvent. The relative optical density (OD) was then measured at a wavelength of $570 \mathrm{~nm}$ using a spectrophotometer (ELISA reader). ${ }^{13,14}$

\section{Anti-amastigote activity}

Resident peritoneal cells from Balb/c mice were plated onto $13 \mathrm{~mm}^{2}$ coverslips inside 24-well plates (TPP, Switzerland ${ }^{\circledR}$ ) and allowed to adhere for $4 \mathrm{~h}$ at $37{ }^{\circ} \mathrm{C}$ in $5 \% \mathrm{CO}_{2}$. The macrophages adhered to the coverslips were infected with Leishmania chagasi as described previously. ${ }^{15}$ Amastigotes obtained from the spleen of experimentally infected hamsters were incubated with adhered macrophages for $2 \mathrm{~h}$ at $37{ }^{\circ} \mathrm{C}, 5 \% \mathrm{CO}_{2}$, at a parasite/macrophage ratio of 10:1. ${ }^{15}$ After the incubation period, non-adherent cells and free parasites were removed by washing with RPMI medium, and the culture was treated with $\mathrm{Sb}^{\mathrm{v}}$-ribonucleosides complexes, meglumine antimoniate or $\left[\mathrm{KSb}(\mathrm{OH})_{6}\right]$, at $10 \mu \mathrm{g} \mathrm{mL}-1$ or $30 \mu \mathrm{g} \mathrm{mL}^{-1}$ of $\mathrm{Sb}$ for $72 \mathrm{~h}$ at $37^{\circ} \mathrm{C}$ in $5 \% \mathrm{CO}_{2}$. Subsequently, the coverslips were removed from the wells, stained with Laborclin ${ }^{\circledR}$ and fixed to a slide with Canada Balsam (Vetec $\left.{ }^{\circledR}\right)$. The number of amastigotes/macrophages and infected cells was determined by counting at least 300 macrophages in duplicate cultures, and the results were expressed as percentage of survival in comparison to that of the controls.

\section{Results and Discussion}

Physicochemical characterization of $S b^{V}$-ribonucleoside complexes

The reaction of $\left[\mathrm{KSb}(\mathrm{OH})_{6}\right]$ with cytidine $(\mathrm{C})$ and uridine $(\mathrm{U})$ led to the formation of 1:1 $\mathrm{Sb}^{\mathrm{V}}$-ribonucleoside complexes that were isolated in the solid state. ESI-MS analyses of these complexes in the negative mode revealed major ions at $\mathrm{m} / \mathrm{z} 430$ and 431, which can be assigned to $\left[\mathrm{SbU}(\mathrm{OH})_{4}\right]^{-}$and $\left[\mathrm{SbC}(\mathrm{OH})_{4}\right]^{-}$, respectively (Supplementary Information).

The two new complexes (Figure 1) were further characterized by ${ }^{1} \mathrm{H}$ and ${ }^{13} \mathrm{C}$ NMR spectroscopy analysis. Tables 1 and 2 display the attribution of ${ }^{1} \mathrm{H}$ and ${ }^{13} \mathrm{C}$ NMR resonances for the $\mathrm{Sb}^{\mathrm{V}}-\mathrm{C}$ and $\mathrm{Sb}^{\mathrm{V}}-\mathrm{U}$ complexes. The assignment of the NMR resonances was achieved using 


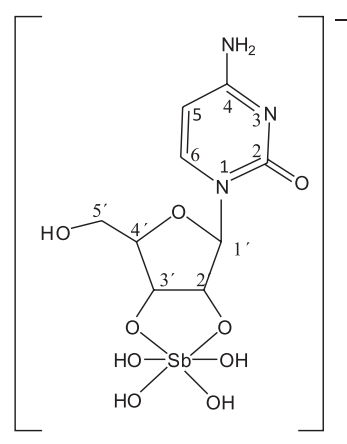

Sb-cytidine $(1: 1)$

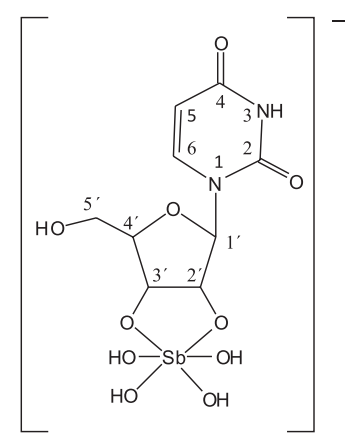

Sb-uridine $(1: 1)$
Figure 1. Structures proposed for the 1:1 Sb-C and Sb-U complexes.
HMBC and HMQC experiments, as illustrated for the $\mathrm{Sb}^{\mathrm{V}}-\mathrm{U}$ complex in Figures $2 \mathrm{~A}$ and $\mathrm{B}$.

The most important changes in NMR parameters resulting from the formation of the complexes were observed for H-4', H-6 (shifted to lower frequencies), H2', H-3' (shifted to higher frequencies), C-1', C-4', C-5' and C-6 (high frequency shift). These can be attributed to a change in the sugar conformation upon binding of $\mathrm{Sb}^{\mathrm{v}}$. Interestingly, the profile of hydrogen resonance changes differed between the $\mathrm{Sb}^{\mathrm{v}}-\mathrm{C}$ and $\mathrm{Sb}^{\mathrm{v}}-\mathrm{U}$ complexes, whereas very similar profiles of carbon resonances changes were observed. Furthermore, these hydrogen resonances
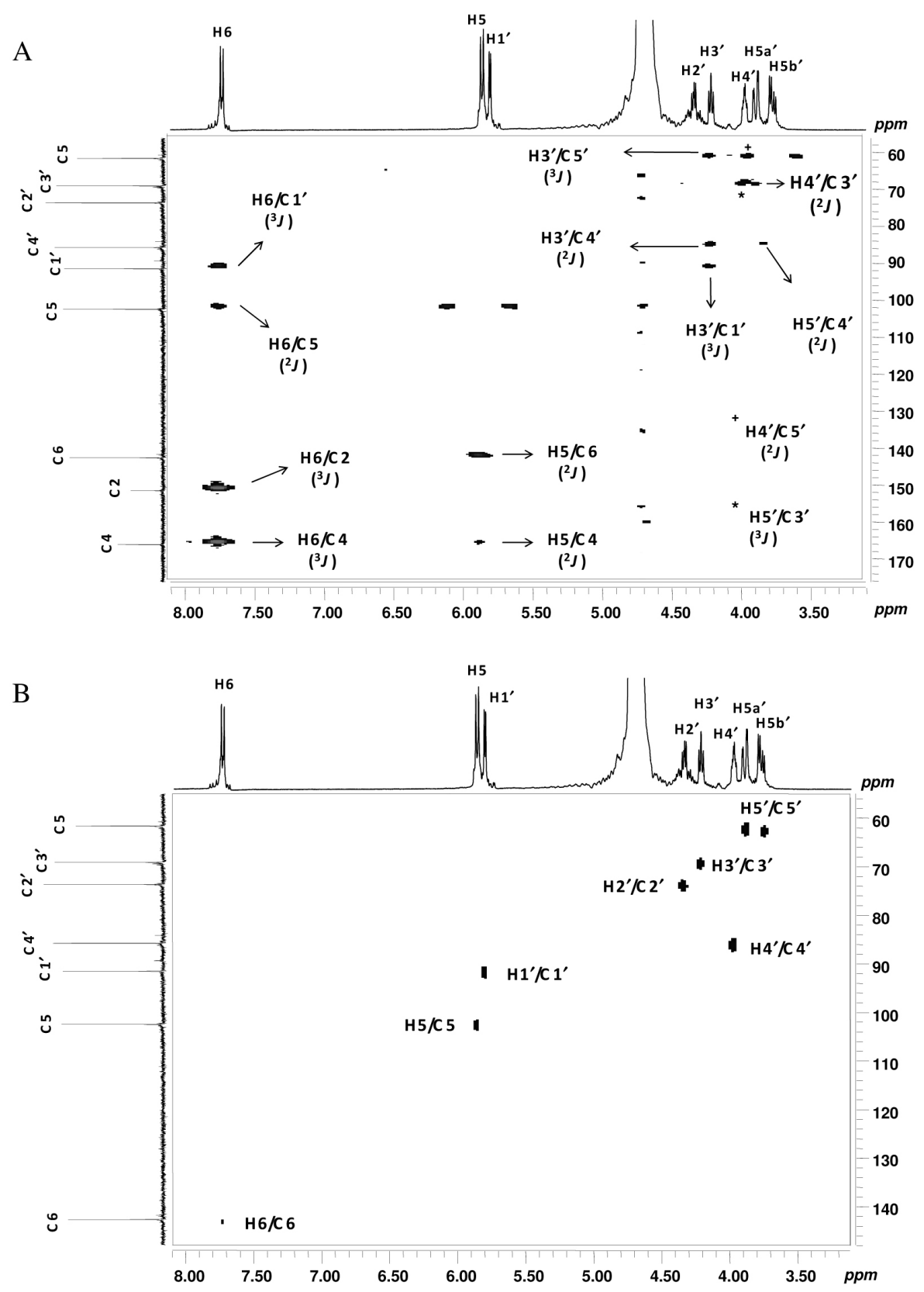

Figure 2. HMBC (A) and HMQC (B) spectra obtained for the $\mathrm{Sb}^{\mathrm{V}}-\mathrm{U}$ complex. 
changes differ from those reported previously for the $\mathrm{Sb}^{\mathrm{V}}$-A complex, ${ }^{5}$ which showed greater changes for $\mathrm{H}-1$ ' and $\mathrm{H}-2$ '.

To further investigate the influence of the nucleobase on the binding of $\mathrm{Sb}^{\mathrm{v}}$ to the ribose moiety, kinetic and thermodynamic parameters were determined for the formation of $1: 1 \mathrm{Sb}^{\mathrm{V}}$ complexes with $\mathrm{C}, \mathrm{U}, \mathrm{A}$ and $\mathrm{G}$ ribonucleosides. Table 3 reports the stability constants $(K)$ and apparent association and dissociation rate constants determined for the different $\mathrm{Sb}^{\mathrm{v}}$-ribonucleoside complexes at $37^{\circ} \mathrm{C}$ and $\mathrm{pD}$ 6.5. Strikingly, $\mathrm{Sb}^{\mathrm{V}}-\mathrm{U}$ showed a significantly higher value of stability constant when compared to $\mathrm{Sb}^{\mathrm{v}}$-C. Since these complexes exhibited comparable values of association rate constants but different dissociation rate constants, the dependence of $K$ upon the nature of the pyrimidine nucleobase could be attributed to differences in the dissociation rate constants of the complexes. Other interesting features of the present data are the lower values of the association and dissociation rate constants of the $\mathrm{Sb}^{\mathrm{V}}$-A complex when compared to the other $\mathrm{Sb}^{\mathrm{V}}$-ribonucleosides complexes.

These data indicate that, although $\mathrm{Sb}^{\vee}$ most probably binds to the same donor atoms in the different nucleosides, the ribose conformational changes induced by its binding and the physicochemical characteristics of the resulting complex depend on the nucleobase.

Table 1. ${ }^{1} \mathrm{H}$ NMR parameters (400 MHz) for cytidine (C) and uridine (U) and their $\mathrm{Sb}^{\mathrm{v}}$ derivatives ( $\mathrm{Sb}^{\mathrm{v}}-\mathrm{C}$ and $\left.\mathrm{Sb}^{\mathrm{v}}-\mathrm{U}\right)$

\begin{tabular}{|c|c|c|c|c|c|c|}
\hline Hydrogen & $\begin{array}{c}\mathrm{C} \\
\delta / \mathrm{ppm}\end{array}$ & $\begin{array}{c}\mathrm{Sb}^{\mathrm{v}}-\mathrm{C} \text { complex } \\
\delta / \mathrm{ppm}\end{array}$ & $\Delta \delta$ & $\begin{array}{c}\mathrm{U} \\
\delta / \mathrm{ppm}\end{array}$ & $\begin{array}{c}\mathrm{Sb}^{\mathrm{V}}-\mathrm{U} \text { complex } \\
\delta / \mathrm{ppm}\end{array}$ & $\Delta \delta$ \\
\hline $1^{\prime}$ & $5.76(d)$ & 5.77 (d) & 0.01 & $* 5.90(\mathrm{~d})$ & $5.86(\mathrm{~d})$ & -0.04 \\
\hline $2^{\prime}$ & $4.17(t)$ & $4.27(\mathrm{t})$ & 0.10 & $4.36(t)$ & $4.39(q)$ & 0.03 \\
\hline $3^{\prime}$ & $4.07(\mathrm{t})$ & $4.18(\mathrm{t})$ & 0.11 & $4.23(t)$ & $4.27(t)$ & 0.04 \\
\hline $4^{\prime}$ & $3.99(\mathrm{~m})$ & $3.92(\mathrm{~m})$ & -0.07 & $4.14(\mathrm{~m})$ & $4.04-3.99(\mathrm{~m})$ & -0.13 \\
\hline $5 a^{\prime}$ & $3.81(\mathrm{dd})$ & 3.84 (d) & 0.03 & $3.92(\mathrm{dd})$ & $3.94(\mathrm{dd})$ & 0.03 \\
\hline $5 b^{\prime}$ & $3.68(\mathrm{dd})$ & $3.74(\mathrm{dd})$ & 0.06 & $3.81(\mathrm{dd})$ & $3.82(\mathrm{dd})$ & 0.02 \\
\hline 5 & $5.90(d)$ & 5.89 (d) & -0.01 & $* 5.89(\mathrm{~d})$ & $5.92(\mathrm{~d})$ & 0.03 \\
\hline 6 & 7.70 (d) & $7.66(d)$ & -0.04 & 7.88 (d) & 7.79 (d) & -0.09 \\
\hline
\end{tabular}

*data from reference 9 .

Table 2. ${ }^{13} \mathrm{C}$ NMR parameters (100 MHz) for cytidine (C) and uridine (U) and their $\mathrm{Sb}^{\mathrm{v}}$ derivatives $\left(\mathrm{Sb}^{\mathrm{v}}-\mathrm{C}\right.$ and $\left.\mathrm{Sb}^{\mathrm{v}}-\mathrm{U}\right)$

\begin{tabular}{|c|c|c|c|c|c|c|}
\hline Carbon & $\begin{array}{c}\mathrm{C} \\
\delta / \mathrm{ppm}\end{array}$ & $\begin{array}{c}\mathrm{Sb}^{\mathrm{v}}-\mathrm{C} \\
\delta / \mathrm{ppm}\end{array}$ & $\Delta \delta$ & $\begin{array}{c}\mathrm{U} \\
\delta / \mathrm{ppm}\end{array}$ & $\begin{array}{c}\mathrm{Sb}^{\mathrm{v}}-\mathrm{U} \\
\delta / \mathrm{ppm}\end{array}$ & $\Delta \delta$ \\
\hline 2 & 157.69 & 157.71 & 0.02 & 151.67 & 151.70 & 0.03 \\
\hline 4 & 166.23 & 166.24 & 0.01 & 166.21 & 166.28 & 0.07 \\
\hline 5 & 96.22 & 96.59 & 0.37 & 102.26 & 102.55 & 0.29 \\
\hline 6 & 141.69 & 142.68 & 0.99 & 141.85 & 142.75 & 0.90 \\
\hline $1^{\prime}$ & 90.38 & 92.13 & 1.75 & 89.41 & 91.57 & 2.16 \\
\hline $2^{\prime}$ & 73.98 & 73.95 & -0.03 & 73.67 & 73.61 & -0.06 \\
\hline $3^{\prime}$ & 69.34 & 69.21 & -0.13 & 69.44 & 69.12 & -0.32 \\
\hline $4^{\prime}$ & 83.80 & 85.67 & 1.87 & 84.41 & 85.81 & 1.40 \\
\hline $5^{\prime}$ & 60.79 & 61.76 & 0.97 & 60.77 & 61.67 & 0.90 \\
\hline
\end{tabular}

Table 3. Stability constants $(K)$ and apparent association and dissociation rate constants $\left(k_{\mathrm{f}}\right.$ and $k_{\mathrm{d}}$, respectively) for different $\mathrm{Sb}^{\mathrm{v}}$-ribonucleoside complexes at $37^{\circ} \mathrm{C}$ in $\mathrm{D}_{2} \mathrm{O}$ containing $0.1 \mathrm{~mol} \mathrm{~L}^{-1} \mathrm{KCl}$ at $\mathrm{pD} 6.5$ (mean \pm standard deviation, $\mathrm{n}=3$ )

\begin{tabular}{lcccc}
\hline & $\mathrm{Sb}^{\mathrm{v}}-\mathrm{U}$ & $\mathrm{Sb}^{\mathrm{V}}-\mathrm{C}$ & $\mathrm{Sb}^{\mathrm{v}}-\mathrm{A}$ & $\mathrm{Sb}^{\mathrm{v}}-\mathrm{G}$ \\
\hline$K\left(\mathrm{~L} \mathrm{~mol}^{-1}\right)$ & $1756 \pm 58$ & $1227 \pm 86$ & $1594 \pm 91$ & - \\
$k_{\mathrm{f}}\left(\mathrm{L} \mathrm{mol}^{-1} \mathrm{~h}^{-1}\right)$ & $158 \pm 8$ & $142 \pm 6$ & $82 \pm 15$ & - \\
$k_{\mathrm{d}}\left(\mathrm{h}^{-1}\right)$ & $0.0155 \pm 0.0022$ & $0.0363 \pm 0.0020$ & $0.0081 \pm 0.0018$ & $0.036 \pm 0.011$ \\
\hline
\end{tabular}




\section{Biological activities of the $S b^{V}$-ribonucleoside complexes}

The different $\mathrm{Sb}^{\mathrm{V}}$-ribonucleoside complexes were evaluated for their cytotoxicity towards murine peritoneal macrophages, as well as for their in vitro activity against L. chagasi parasite in the Leishmania-infected macrophage system. Figure 3 shows the cytotoxicity of different $\mathrm{Sb}^{\mathrm{V}}$ complexes towards macrophages at 10 and $100 \mu \mathrm{gL}^{-1}$ of Sb. Antimoniate and meglumine antimoniate were also evaluated in the same assay. Although none of the antimonial compounds was found to be toxic at $10 \mu \mathrm{g} \mathrm{mL}^{-1}$, the following complexes showed cytotoxicity at $100 \mu \mathrm{g} \mathrm{mL} \mathrm{m}^{-1}$ according to the order: $\mathrm{Sb}-\mathrm{G}>\left[\mathrm{KSb}(\mathrm{OH})_{6}\right]>\mathrm{Sb}-\mathrm{A}>\mathrm{Sb}-\mathrm{C}>\mathrm{Sb}-\mathrm{U}$.

Interestingly, the higher toxicity of antimoniate when compared to most $\mathrm{Sb}^{\mathrm{V}}$-complexes suggests that the complexation of $\mathrm{Sb}^{\mathrm{V}}$ reduces its cytotoxicity, presumably by promoting a slow release system for $\mathrm{Sb}^{\mathrm{v}}$. This result is consistent with the higher cytotoxic activity of antimoniate against a tumor cell line, when compared to meglumine
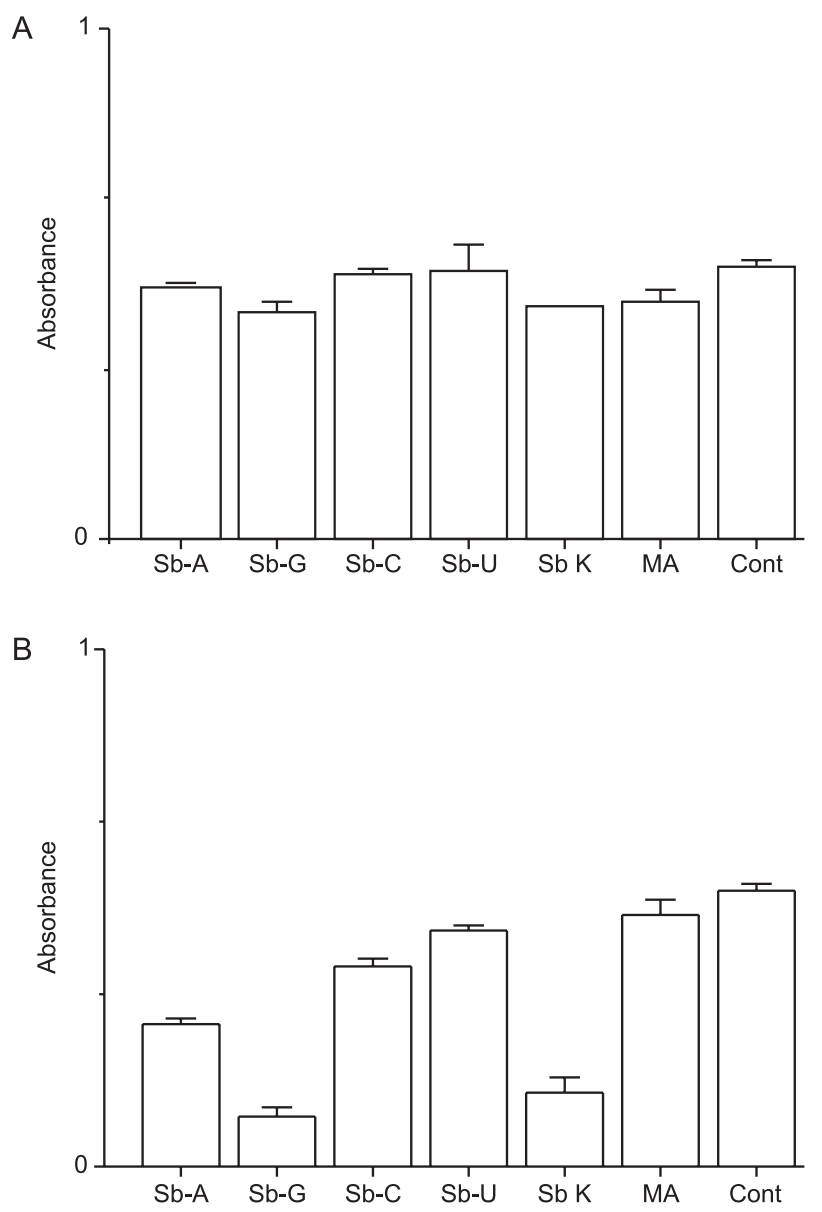

Figure 3. Cytotoxicity of different $\mathrm{Sb}^{\mathrm{v}}$ complexes against murine macrophage at $10 \mu \mathrm{g} \mathrm{mL}^{-1}$ of $\mathrm{Sb}(\mathrm{A})$ and $100 \mu \mathrm{g} \mathrm{mL}^{-1}$ of Sb (B), as determined by the MTT assay. "Sb K" and MA represent $\left[\mathrm{KSb}(\mathrm{OH})_{6}\right]$ and meglumine antimoniate, respectively. "Cont" represents untreated control. Data are shown as means of absorbance \pm standard error $(n=3)$. antimoniate. ${ }^{16}$ In the case of $\mathrm{Sb}^{\mathrm{V}}-\mathrm{C}, \mathrm{Sb}^{\mathrm{V}}-\mathrm{U}$ and meglumine antimoniate, an inverse relationship was observed between the stability constant of the complex and its cytotoxicity. Thus, no significant cytotoxicity of the highly stable complex meglumine antimoniate ${ }^{4}$ was observed, even at $100 \mu \mathrm{g} \mathrm{mL}^{-1}$ of Sb.

Figure $4 \mathrm{~A}$ displays the in vitro antileishmanial activity of the different $\mathrm{Sb}^{\mathrm{V}}$-ribonucleoside complexes at $10 \mu \mathrm{g} \mathrm{mL}^{-1}$ of $\mathrm{Sb}$. A significant reduction of the fraction of infected macrophages was observed only in the case of Sb-A and $\mathrm{Sb}-\mathrm{G}$ complexes. Interestingly, these complexes were found to be more effective than the first-line antileishmanial drug meglumine antimoniate. Figure 4B illustrates that meglumine antimoniate, although inactive at $10 \mu \mathrm{g} \mathrm{mL}-1$ of $\mathrm{Sb}$, promoted a significant reduction of the fraction of infected macrophage at $30 \mu \mathrm{g} \mathrm{mL}^{-1}$ of Sb.

The high cytotoxicity towards host cells of $\mathrm{Sb}^{\mathrm{V}}$-purine nucleoside complexes suggests that the formation of these complexes in the vertebrate host may contribute to the
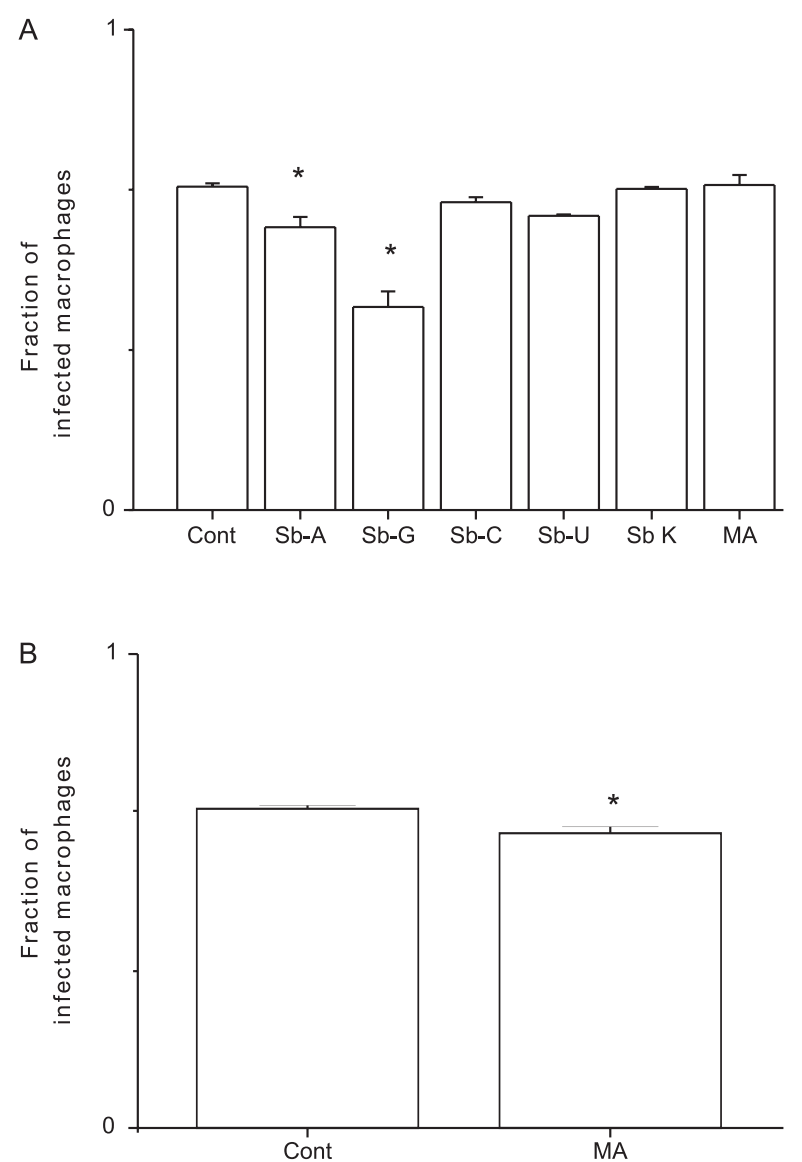

Figure 4. In vitro antileishmanial activity of different $\mathrm{Sb}^{\mathrm{v}}$ complexes at $10 \mu \mathrm{g} \mathrm{mL} \mathrm{m}^{-1}$ of Sb (A) and $30 \mu \mathrm{g} \mathrm{mL} \mathrm{s}^{-1}$ of Sb (B) in the Leishmania chagasiinfected macrophage model. "Sb K" and MA represent $\left[\mathrm{KSb}(\mathrm{OH})_{6}\right]$ and meglumine antimoniate, respectively. "Cont" represents untreated control. Data are shown as means of fraction of infected macrophage \pm standard error $(\mathrm{n}=2)$. $* P<0.05$ according to One-way ANOVA, followed by Newman Keuls multiple comparison Post-test. 
side effects of pentavalent antimonial drugs. ${ }^{1}$ Furthermore, the higher antileishmanial activities of Sb-A and Sb-G complexes also support the model that the interaction of $\mathrm{Sb}^{\mathrm{V}}$ with purine nucleosides may mediate the antileishmanial action of pentavalent antimonial drugs. According to this model, following treatment with an antimonial drug such as meglumine antimoniate, the drug would reach macrophage phagolysosomes in which the Leishmania parasite resides, either by simple diffusion or following binding to the cell surface and subsequent endocytosis. $\mathrm{Sb}^{\mathrm{V}}$ purine nucleoside complexes would then be formed within the phagolysosomes. The formation of these complexes is supported by both biological and physicochemical features. Since Leishmania is a true auxothroph for purine, its survival depends on the capture of purine ribonucleosides from the host. ${ }^{8}$ Therefore, purine ribonucleosides are expected to be present in significant amount within phagolysosomes. Furthermore, the stability constants determined for $\mathrm{Sb}^{\mathrm{V}}-\mathrm{A}$ and $\mathrm{Sb}^{\mathrm{V}}-\mathrm{GMP}^{4}$ are consistent with the in vivo formation of these complexes. In addition, the $\mathrm{pH}$ dependence of the rate of formation of Sb-ribonucleosides ${ }^{4}$ indicates that this reaction would be kinetically favored in the acidic environment of phagolysosomes. Ultimately, the $\mathrm{Sb}^{\mathrm{V}}$-purine nucleoside complexes may kill the parasites, through inhibition of the Leishmania purine transporters or interference with the purine salvage pathway. ${ }^{8}$

\section{Conclusions}

The present work indicates for the first time that, although $\mathrm{Sb}^{\mathrm{v}}$ most probably binds via oxygen atoms to the same $2^{\prime}$ and $3^{\prime}$ positions in the different nucleosides, the ribose conformational changes induced by its binding and the physicochemical characteristics of the resulting complexes depend on the nucleobase. It is also established that the nucleobase has a strong influence on the cytotoxicity and antileishmanial activity of the $\mathrm{Sb}^{\mathrm{V}}$-ribonucleoside complex, the $\mathrm{Sb}^{\mathrm{v}}$-purine nucleoside complexes being more cytotoxic towards macrophages and more effective against Leishmania chagasi than their $\mathrm{Sb}^{\mathrm{V}}$-pyrimidine nucleoside analogues. The higher cytotoxicities of $\mathrm{Sb}-\mathrm{A}$ and $\mathrm{Sb}-\mathrm{G}$ towards both Leishmania and host cells also support the model that the interaction of $\mathrm{Sb}^{\mathrm{v}}$ with purine nucleosides may mediate the toxicity and antileishmanial activity of pentavalent antimonial drugs.

\section{Supplementary Information}

Supplementary information related to the ESI-MS analysis of the $\mathrm{Sb}^{\mathrm{V}}-\mathrm{C}$ and $\mathrm{Sb}^{\mathrm{v}}-\mathrm{U}$ complexes is available free of charge at http://jbcs.org.br, as a PDF file.

\section{Acknowledgments}

This work was supported by the Brazilian agencies CNPq, CAPES and FAPEMIG. R. L. M. N. and C. S. F. were recipients of studentships from CNPq. C. S. F. is a CNPq post-doctoral fellow and C. D., F. F. and M. N. M. are CNPq research fellows.

\section{References}

1. Berman, J. D.; Clin. Infect. Dis. 1997, 24, 684; Frézard, F.; Demicheli, C.; Ribeiro, R. R.; Molecules 2009, 14, 2317.

2. Burguera, J. L.; Burguera, M.; Petit de Pena, Y.; Lugo, A.; Anez, N.; Trace Elem. Med. 1993, 10, 66; Goodwin, L. C.; Page, J. E.; Biochem. J. 1943, 22, 236; Shaked-Mishan, P.; Ulrich, N.; Ephros, M.; Zilberstein, D.; J. Biol. Chem. 2001, 276, 3971; Ferreira, C. S.; Martins, P. S.; Demicheli, C.; Brochu, C.; Ouellette, M.; Frézard, F.; Biometals 2003, 16, 441; De Oliveira, F. B.; Schettini, D. A.; Ferreira, C. S.; Rates, B.; Rocha, O. G. F.; Frézard, F.; Demicheli, C.; J. Braz. Chem. Soc. 2006, 17, 1642.

3. Demicheli, C.; Frézard, F.; Lecouvey, M.; Garnier-Suillerot, A.; Biochim. Biophys. Acta 2002, 1570, 192.

4. Chai, Y.; Yan, S.; Wong, I. L. K.; Chow, L. M. C.; Sun, H.; J. Inorg. Biochem. 2005, 99, 2257; Ferreira, C. S.; Pimenta, A. M. C.; Demicheli, C.; Frézard, F.; Biometals 2006, 19, 573.

5. Demicheli, C.; Santos, L. S.; Ferreira, C. S.; Bouchemal, N.; Hantz, E.; Eberlin, M. N.; Frézard, F.; Inorg. Chim. Acta 2006, $359,159$.

6. Hansen, H. R.; Pergantis, S. A.; Anal. Bioanal. Chem. 2006, 385,821 .

7. Roberts, W. L.; Berman, J. D.; Rainey, P. M.; Antimicrob. Agents Chemother. 1995, 39, 1234.

8. Marr, J.; J. Lab. Clin. Med. 1991, 118, 111.

9. Deslauries, R.; Smith, I. C. P.; Can. J. Chem. 1973, 51, 833.

10. Demicheli, C.; Ochoa, R.; Lula, I. S.; Gozzo, F. C.; Eberlin, M.; Frézard, F.; Appl. Organomet. Chem. 2003, 17, 226.

11. Glasoe, P. K.; Long, F. A.; J. Phys. Chem. 1960, 64, 188.

12. Mosmann, T.; J. Immunol. Methods 1983, 65, 55.

13. Dutta, A.; Bandyopadhyay, S.; Mandal, C.; Chatterjee, M.; Parasitol. Int. 2005, 54, 119.

14. Tempone, A. G.; Perez, D.; Rath, S.; Vilarinho, A. L.; Mortara, R. A.; Andrade, H. F.; J. Antimicrob. Chemother. 2004, 54, 60.

15. Eslami, Z.; Tanner, C.; Int. J. Parasitol. 1994, 24, 743.

16. Dzamitika, S. A.; Falcão, C. A.; Oliveira, F. B.; Marbeuf, C.; Garnier-Suillerot, A.; Demicheli, C.; Rossi-Bergmann, B.; Frézard, F.; Chem. Biol. Int. 2006, 160, 217.

Received: September 13, 2009

Web Release Date: April 15, 2010 


\section{Influence of the Nucleobase on the Physicochemical Characteristics and Biological Activities of $\mathrm{Sb}^{\mathrm{V}}$-Ribonucleoside Complexes}

Cláudio S. Ferreira, ${ }^{a, b}$ Iara C. M. da Rocha, ${ }^{c}$ Rubens L. M. Neto, ${ }^{b}$ Maria N. Melo, ${ }^{c}$

Frédéric Frézard ${ }^{b}$ and Cynthia Demicheli*a

${ }^{a}$ Departamento de Química, ICEx, ${ }^{b}$ Departamento de Fisiologia e Biofísica, ICB and

${ }^{c}$ Departamento de Parasitologia, ICB,Universidade Federal de Minas Gerais, Av. Antônio Carlos 6627, 31270-901 Belo Horizonte - MG, Brazil

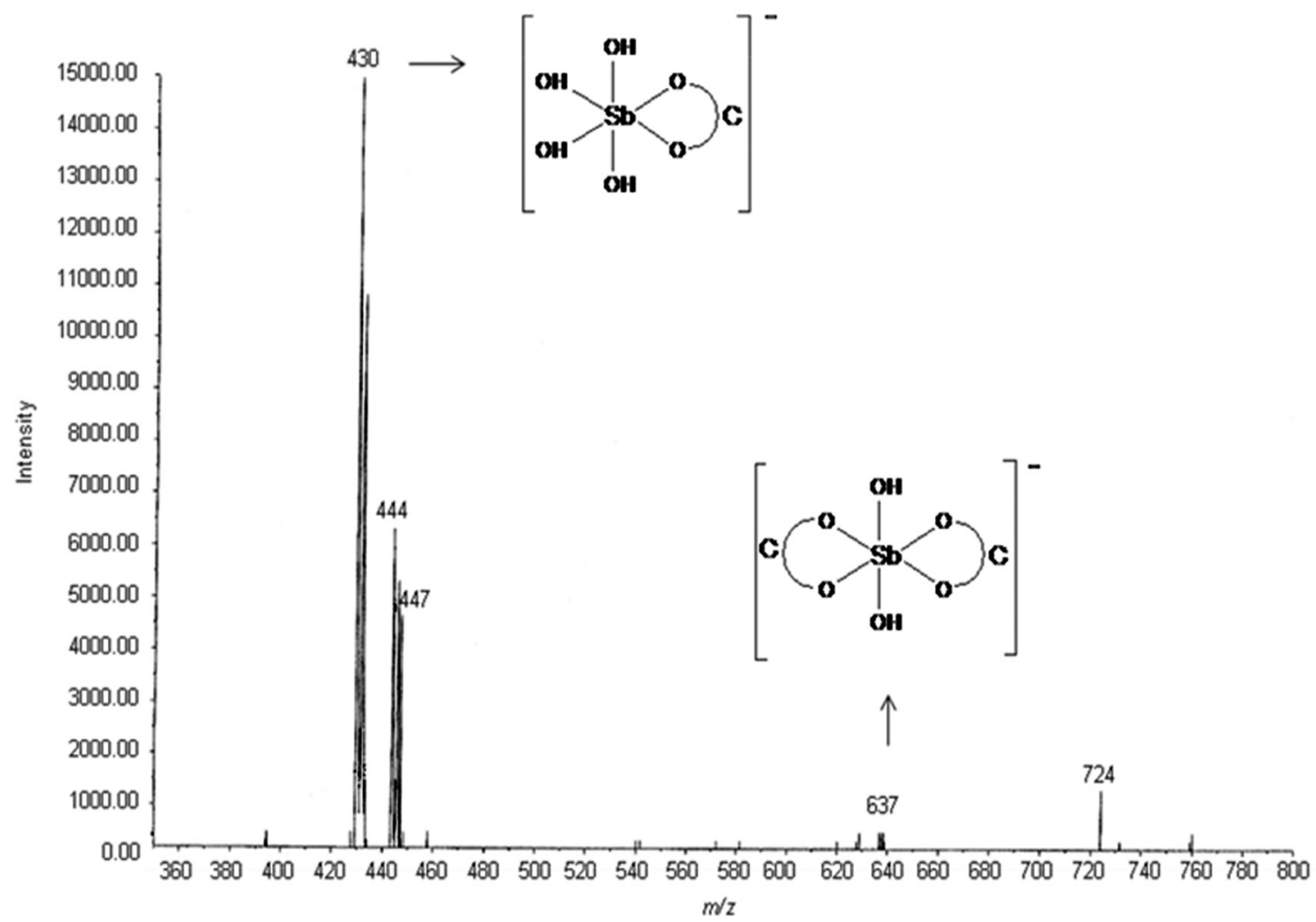

Figure S1. Negative ESI-MS spectrum of $\mathrm{Sb}^{\mathrm{V}}-\mathrm{C}$. 


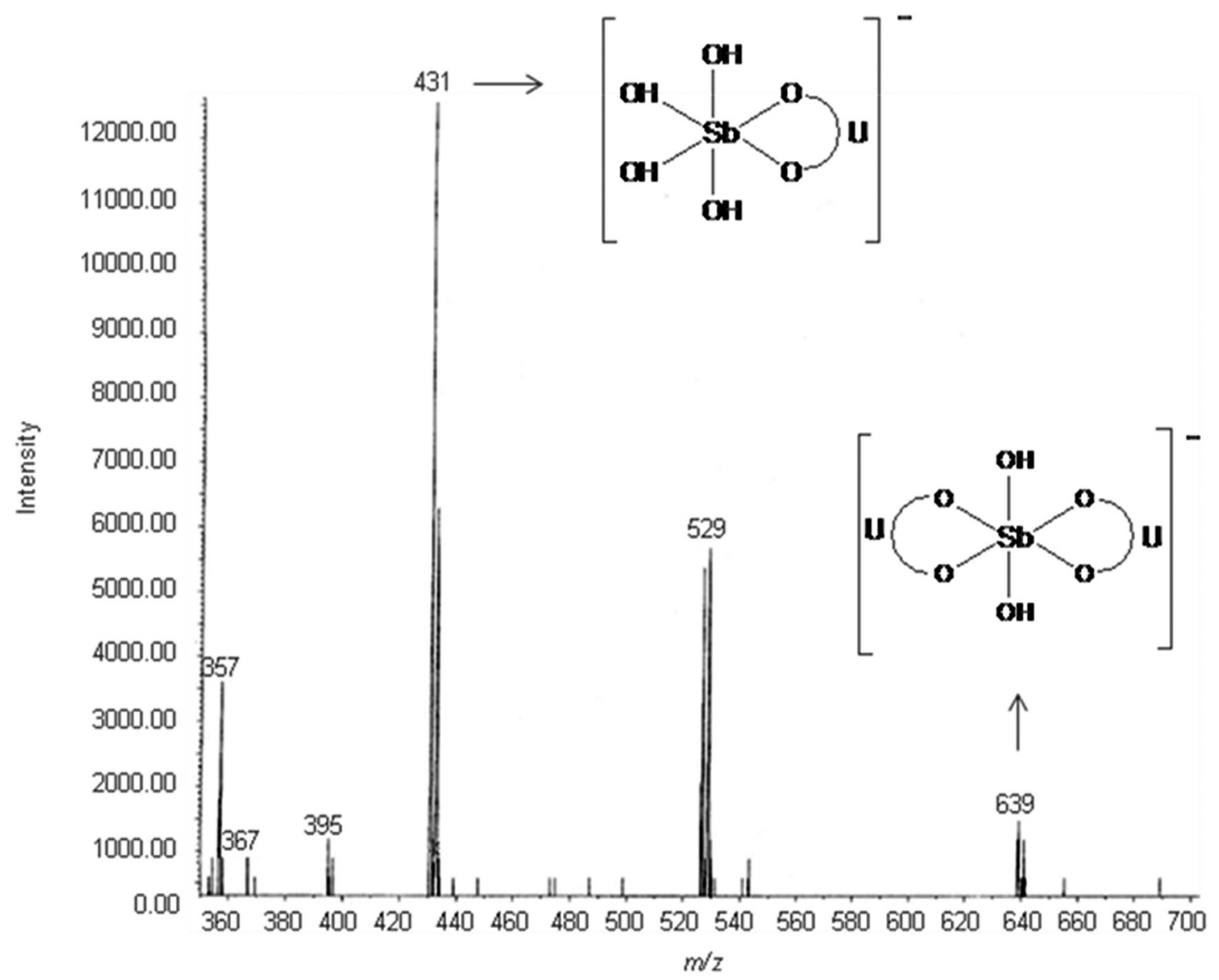

Figure S2. Negative ESI-MS spectrum of $\mathrm{Sb}^{\mathrm{v}}-\mathrm{U}$. 